\title{
Contracts as a facilitator of resource evolution
}

\author{
Stefanos Mouzas ${ }^{\mathrm{a}, *}$, David Ford ${ }^{\mathrm{b}}$ \\ a Lancaster University Management School, Lancaster, England, United Kingdom \\ b Euromed Management, Marseille, France
}

\section{A R T I C L E I N F O}

\section{Article history:}

Received 1 July 2011

Received in revised form 1 October 2011

Accepted 1 October 2011

Available online 3 December 2011

\section{Keywords:}

Resource

Leverage

Contracts

Interaction

Knowledge

\begin{abstract}
A B S T R A C T
The formality of contracts is not external to the substance of business interactions, but a way of articulating, facilitating and simplifying the complexity of business interactions. An umbrella contract, in particular, is an abstraction of possibility and a refined version of the substance of business interaction in which resource leveraging may or may not occur. Umbrella contracts circumscribe an in-built platform or 'architecture' that enables regular and repeated knowledge-intensive interactions. Today's business landscape is characterized by the heterogeneity of resources, activities and actors and contracts have become a key element in the interconnected path of resource evolution, activity specialization and actor co-evolution.
\end{abstract}

(c) 2011 Elsevier Inc. All rights reserved.

\section{Introduction}

Carl Johan Hatteland's commentary on "Leveraging knowledgebased resources: the role of contracts" (2011) is both inspiring and thought-provoking. The commentary acknowledges that the study (Mouzas \& Ford, 2011) is an important step in linking ideas of business contracts and resource interaction in relational settings. The commentary argues that the findings provide new and valuable insight into the role of contracts in business relationships in general and the leveraging of knowledge-based resources in particular. Simultaneously, the commentary expresses new and relevant questions that require the development of new avenues of inquiry.

The core of Hatteland's commentary is that the article consigns contracts into a rather large and unspecified category of contextual factors that are external to a relationship, but that in this case may influence the relationship by leveraging knowledge-based resources (Hatteland, 2011). This view relates to the commonly held beliefs that a contract is a formal device which is external to the substance of business interactions and that the primary function of a contract is to control a counterpart. However, the formality of contracts is not external to the substance of business interactions, but a way of articulating, preserving and facilitating that substance (Stinchcombe, 2001).

\footnotetext{
is The authors thank Sylvia Lacoste of Rouen Business School, France; and Peter Naude of Manchester Business School, England for valuable comments and suggestions.

* Corresponding author.

E-mail addresses: S.Mouzas@lancaster.ac.uk (S. Mouzas), David.Ford@euromed-management.com (D. Ford).
}

An umbrella contract, in particular, is an abstraction of possibility; a refined version of this substance. This means that umbrella contracts circumscribe an in-built platform, where common knowledge may or may not occur through interaction among counterparts. For this reason, the same platform used by different contracting actors may result in different resource combinations in different interaction processes (Ford, Gadde, Håkansson, \& Snehota, 2011; Håkansson, Ford, Gadde, Snehota, \& Waluszewski, 2009). Thus, the primary function and concern of contracts in continuing relationships marked by recurrent interactions is not that of counterpart-control or the detection of deceit or betrayal. Instead, contracts are part of the process of leveraging knowledge-based resources to facilitate the creation of joint gains and thus improve the competiveness of both counterparts in a business relationship (Collins, 2009). For example, consider the umbrella contract between Wal-Mart and Procter \& Gamble, in which Procter \& Gamble serves as "category captain," a term equivalent to preferred supplier. In this contract, Procter \& Gamble as category captain transfers industry knowledge to Wal-Mart with regard to a specific category of products, e.g. market research, product specification, consumer data etc. and in return, Wal-Mart transfers 'retail' knowledge to Procter \& Gamble with regard to "shopper insight" connected with scanner data at the point of sale.

Do contracts requirements include setting-up resource interfaces, or can they be organized by more informal channels? Undoubtedly, actors may choose to organize their resource interfaces in more informal ways. Why then do companies opt for formality? Business actors choose to formalize the agreements with their counterparts for two compelling reasons.

First, today's business interaction reveals multiple levels of interface (Håkansson, 1982) and resource combination between different 
departments such as sales, purchasing or marketing, different regional centers such as business units or distributors and different front-line sales managers and buyers (Mouzas, 2006). Thus, contracts are useful because they institutionalize the multiplicity of interfaces by creating a shared understanding in the sense of shared mind-set based on a set of reference points (Fehr, Hart, \& Zehnder, 2011; Hart \& Moore, 2008). Contracts also secure commitments, especially when actors change or when relevant players move within organizations. In this way, contracts create the 'architecture' that enables regular and repeated knowledgeintensive interactions.

Second, the enforceability of informal agreements remains extremely limited. Notwithstanding the existence of 'self-enforcing' agreements that involve non-legal sanctions such as reputation costs or the loss of relationship-specific assets (Charny, 1990; Levin, 2003; Scott, 2003), contemporary business agreements are manifested in legally enforceable contracts. For this reason, sellers and buyers need to formalize their agreements and they need to draw on the expertise of corporate lawyers or legal departments to formulate force-majeure clauses, exit terms or termination clauses. The need for formality is demonstrated vividly in an extensive analysis of relational contracts in US courts (see Schwartz, 1992) and the leading case in the United Kingdom (Baird Textile Holdings Limited vs. Marks \& Spencer plc., 2001) where senior English judges vigorously rejected any attempt to enforce any informal, non-contractual agreements (Blois, 2003; Harrison, 2004; Mellahi, Jackson, \& Sparks, 2002)

Are umbrella contracts specific to this particular kind of industry, or do they apply across industries? An inspection of the existing contractual agreements in several industries such as financial services, banking, pharmaceuticals, biotechnology, manufacturing and retailing shows that umbrella contracts mirror the reality of business relationships today because companies are not concerned with immediate contractual decisions. Instead, they are concerned with the explicit framework of norms within which contractual decisions can be made (Mouzas \& Ford, 2006; Mouzas \& Furmston, 2008).

The common denominator of all these industries is not that endcustomers are shared, but that interaction among counterparts is regular, for example, in the form of annual negotiations and quarterly or monthly business reviews. For this reason, umbrella contracts are a signal that products or services are ordered regularly from a supplier or are sold regularly to a customer.

Hatteland (2011) raises the question of whether something could be imbued in the contractual arrangement to make a specific relationship increasingly exclusive and dedicated. The answer is that there is no evidence that supports this suggestion. Despite the widespread use of exclusivity clauses, exclusive and dedicated relationships are more likely to be a function of the ability of counterparts to either create joint value or exercise available alternative options in their surrounding networks. This proposition links with two important implications: the first is that umbrella contracts do not pre-determine future selection processes. Ordering processes, for example, may vary from region to region or from outlet to outlet; and will finally be determined by the evolving customer demand. The second implication is that an 'architecture' that enables regular and repeated knowledge-intensive interactions does not imply that this consensus is necessarily a long-term contract. The ability to sustain the creation of joint value and the inherent competition within a network of relationships will determine whether a specific business relationship will remain exclusive and dedicated.

The commentary (Hatteland, 2011) questions whether umbrella contracts are primarily about expressing joint consent to share information about a range of products leading to the development of resource interfaces or simply for swapping information in return for discounts. Discounts or trade allowances are the significant resources that manufacturers exchange in return for the shelf space (also a resource) that retailers may offer for manufacturers' products. The study (Mouzas \& Ford, 2011) suggests that umbrella contracts are not concerned with specific exchanges, such as swapping information for discounts. Instead, umbrella contracts are concerned with the explicit framework of norms within which exchanges and wider interaction may or may not take place. In this way, umbrella contracts may represent a joint consent that regulates the use of trade allowances and information exchange. This is demonstrated in umbrella agreements between manufacturers and retailers to implement Efficient Consumer Response (ECR) in complex manufacturer-retailer networks. Specifically, leading fast-moving consumer goods manufacturers used trade allowances as an incentive to promote Electronic Data Interchange with retailers that initially were reluctant to engage in such an exchange process (Mouzas \& Araujo, 2000).

The Industrial Marketing and Purchasing (IMP) Group provides a large number of wide ranging international studies into management in complex business networks, such as those that involve manufacturerretailer relationships, manufacturer-supplier relationships or serviceprovider relationships. The group's interaction approach is based on the importance for both researchers and managers of understanding these complex business networks and the interaction between active buyers and sellers in continuing business relationships. Active buyers and sellers embrace umbrella contracts in their business relationships because they simplify, speed up and facilitate the complex process of business interaction as many of the stratified procedures are predefined in the contract.

The study (Mouzas \& Ford, 2011) does not explicitly address the views of resources contained within earlier IMP research that Hatteland mentions. However, the view of resources on which the article is based is congruent with the most recent IMP articulation of ideas on resources (Ford et al., 2011; Håkansson \& Waluszewski, 2002, 2007; Håkansson et al., 2009; Naude, Salle, Michel, \& Valla, 2003). In particular, this view emphasizes the heterogeneity of business resources (and of activities and actors themselves) in network space. More importantly, this view of resource heterogeneity would see contracts as a key element in the interconnected path of resource evolution, activity specialization and actor co-evolution.

In conclusion, Hatteland's commentary is an insightful critique of the paper on the role of contracts on leveraging knowledge-based resources (Mouzas \& Ford, 2011). The commentary expands the contractual perspective and incorporates new relevant questions and opens new avenues of inquiry on resource evolution. Further business research needs to include the investigation of how contracts build on the resource heterogeneity that is inherent in business networks to pave the way of counterparts' inter-action and co-evolution.

\section{References}

Blois KJ. B2B "relationships": a social construction of reality? A study of Marks and Spencer and one of its major suppliers. Marketing Theory 2003;3(1):79-95.

Charny D. Nonlegal sanctions in commercial relationships. Harvard Law Review 1990;103:373-467.

Collins H. The weakest link: legal implications of the network architecture of supply chains. In: Marc Amstutz, Gunther Teubner, editors. Networks. Legal Issues of Multilateral Co-operation. Oxford and Portland: Hart Publications; 2009. p. 187-210.

Fehr E, Hart O, Zehnder C. Contracts as reference points-experimental evidence. American Economic Review 2011;101(2):493-525.

Ford D, Gadde L-E, Håkansson H, Snehota I. Managing business relationships. 3rd ed. Chichester: John Wiley; 2011.

Håkansson $\mathrm{H}$. International marketing and purchasing of industrial goods: an interaction approach. Chichester: John Wiley and Sons Ltd.; 1982.

Håkansson $\mathrm{H}$, Waluszewski A. Managing technological development: IKEA, the environment and technology. London: Routledge; 2002.

Håkansson H, Waluszewski A, editors. Knowledge and innovation in business and industry. The importance of using others. London, New York: Routledge; 2007.

Håkansson H, Ford D, Gadde L-E, Snehota I, Waluszewski A. Business in networks. Chichester: John Wiley; 2009.

Harrison D. Is a long-term relationship an implied contract? Two views of relationship disengagement. Journal of Management Studies 2004:41(1):107-25.

Hart O, Moore J. Contracts as reference points. Quarterly Journal of Economics 2008;123:1-48.

Hatteland CJ. Commentary on leveraging knowledge-based resources: the role of contracts. Journal of Business Research 2011. doi:10.1016/j.jbusres.2011.05.016.

Levin J. Relational incentive contracts. American Economic Review 2003;93(3):835-57.

Mellahi K, Jackson P, Sparks L. An exploratory study into failure in successful organizations: the case of Marks and Spencer. Br J Manage 2002;13(1):15-30. 
Mouzas S. Negotiating umbrella agreements. Negotiation Journal 2006;22(3):279-301. Mouzas S, Araujo L. Implementing programmatic initiatives in manufacturer-retailer networks. Industrial Marketing Management 2000;29(4):293-303.

Mouzas S, Ford D. Managing relationships in showery weather: the role of umbrella agreements. Journal of Business Research 2006;59:1248-56.

Mouzas S, Ford D. Leveraging knowledge-based resources: the role of contracts. Journal of Business Research 2011. doi:10.1016/j.jbusres.2011.05.015.

Mouzas S, Furmston M. From contract to umbrella agreement. Cambridge Law Journal 2008;67(1):37-50.
Naude P, Salle R, Michel D, Valla J-P. Business-to-business marketing. Basingstoke: Palgrave; 2003.

Schwartz A. Relational contracts in courts: an analysis of incomplete agreements and judicial strategies. The Journal of Legal Studies 1992;21(2):271-318.

Scott RE. A theory of self-enforcing indefinite agreements. Columbia Law Rev 2003;103(7):1641-99.

Stinchcombe AL. When formality works. Chicago and London: The University of Chicago Press; 2001. 